\title{
Immune Response Indicated by Expressing of IL-2 and IL-10 in Cervical Cancer
}

\author{
Adi Prayitno1, Okid Parama Astirin², Suhartono Taat Putra ${ }^{3}$ \\ ${ }^{1}$ Department of Pathobiology, Faculty of Medicine, University of Sebelas Maret, Surakarta, Indonesia \\ ${ }^{2}$ Departement of Biology, Faculty of Mathematic and Natural Science, University of Sebelas Maret, Surakarta, \\ Indonesia \\ ${ }^{3}$ Department of Pathobiology, Faculty of Medicine, University of Airlangga, Surabaya, Indonesi \\ Email: drgadiprayitno@yahoo.com
}

Received 29 January 2014; revised 25 February 2014; accepted 5 March 2014

Copyright (C) 2014 by authors and Scientific Research Publishing Inc.

This work is licensed under the Creative Commons Attribution International License (CC BY).

http://creativecommons.org/licenses/by/4.0/

(c) (i) Open Access

\begin{abstract}
Introduction: Interleukin-2 (IL-2) is multiple which functions during an inflammatory response. Inflammation is a critical component of cancer progression. IL-10 is the most important cytokine with anti-inflammatory properties. Cancer patients typically show depression of both cellular and humoral immune functions. Aims: The objective of this experiment is to know the expression of IL-2 and IL-10 in cervical cancer. Method: Paraffin block of the tissues frozen section cervical cancer was cut in sharp and cleaned cryotome and place in glass plate that covered with poly-elysine. The immunohistochemistry stains were done with monoclonal antibody anti IL-2 and IL-10 with TSA-indirect method. The collected data were analyzed with T Test (SPSS for window 15). Result: In this study the expression of IL-2 (35.9\% = moderate) is less than the expression of IL-10 (45.3\% $=$ moderate). From $T$ Test analysis of $p<=0.153$, it means that there is no significance in difference between IL-2 and IL-10. Conclusion: We indicated that the immune response plays a role in balance between cellular and humoral immunity.
\end{abstract}

\section{Keywords}

IL-2, IL-10, Immune Response, Cancer

\section{Introduction}

Cytokines are soluble glycoproteins produced by cells used for growth and differentiation. Interleukin as a glycoprotein is produced by lymphocytes for its activity, but now interleukins are also produced by other cells such as fibroblastus, macrophages, monocytes, neuronal cells, and so forth ceratocyte [1]. Until now we know 37 
kinds of interleukin [2]. Interleukin-2 (IL-2) was first known as a growth factor for T lymphocytes. This cytokine naming refers to its function as a $\mathrm{T}$ lymphocyte cell growth factor, which is produced by $\mathrm{T}$ lymphocyte cells. In fact IL-2 also works as a growth and differentiation factor for NK cells, some B lymphocytes, and lymphokine-activated killer (LAK) cells [1] [3]. Interleukin-10 (IL-10) is a cytokine which is very important as the balance of the proinflammatory cytokines. IL-10 can suppress the production of IL-2, IL-3, Tumor Necrosis Factor (TNF), Granulocyte-macrophage Colony Stimulating Factor (GM-CSF) and interferon gamma (IFNgamma) and the expression of major histocompatability complex class II (MHC-II) in macrophages. B lymphocyte cell growth and the production of immunoglobulin (Ig) remained normal in rats that were made unable to produce IL-10 [1] [4]. How the outlook for the expression of IL-2 and IL-10 that has a function opposable it in of cancer disease should be known, because it would have been implied to treatment.

Cervical cancer is the most common form of malignancy found in women. Malignancy is found in countries emerging as a common cause of death in women in the world in general which is associated with malignancy. Currently the pathogenesis of cervical cancer is focused on the presence of human papilloma virus (HPV) [5] [6]. Causes of cancer are divided into 2 groups, namely: the environment and genetics that is lowered. Cancer beginning of the trigger environment, not kondisif will continue influencing on material genetic and on the occurrence of some risks of cancer. A factor that pollutes the environment is among others: diet and obesity, tobacco, infection, radiation, and physical activity which didn't fit. Environmental factors cause or trigger keabnormalanmatériel genetic of the cell [7] [8]. The prevalence of cancer is increasing especially in Africa. Estimation of the incidence of this disease is 2.5 per 100,000 population in developing countries [9]. Urbanization and an increase in a chance on the use of tobacco on various forms of such chance of discharging alcohol will clearly increase the incidence of the cancer [10] [11]. As the rate in pain cancer is quite high, the handling of the disease is very urgent. So an increase in the quality of human resources as soon as possible is wished.

The relation between cytokine, increase in the immune response and cure cancer may be covered through the science of patho-biology that is a branch of the science of pathology anatomy and parallel to the science of patho-physiology [12] [13] in the concept of perception of cells and cell response [14]-[16].

The immune system is very important for the sustainability of life and human life. Immunity cellular is always very important to be maintained, and among others it is keeping those immune to walking. Pain that is precipitated by distress was recorded $70 \%-80 \%$ of all patients who come to the doctor [17] [18]. Biological stressors have the possibility of a major role in patogenesis scene cancers as carcinoma. However, the results of research on carcinoma still varies, namely from no relation to dealing very strong [17] [19]. Human papilloma virus is one of biological stressors known as risk factors closely associated with cancer [20]. The inflammation is a critical component of cancer progression which was under research and now becoming clear that the cancer microenvironment was orchestrated by inflammatory cells [21]-[23]. In the termination of inflammatory immune responses, the IL-2 was quite contributed [24]. On the other hand, increased levels of interleukin (IL)-10 have been described as an immunosuppressive condition and as a negative prognostic indicator for survival in patients with various types of cancers [25]-[27].

\section{Methods}

Nineteen frozen tissue sections were collected from patients with cervical cancer at the obstetric and gynecologic Muwardi Doctors Hospital Surakarta. Paraffin tissue had blocked a clean cut using a microtome and placed on a glass plate results that have been smeared with poly-elisen.

The diagnoses that deals with fierceness performed by a pathologist base tohistopatology picture.

Immunohistochemical stains performed with TSA-indirect method (NEN Life Science Products, renaissence) using a monoclonal antibody anti-IL-2 (1:500) and IL-10 (1:500) (Santa Cruz Biotech, Amersham Pharmacia Biotech) [28] [29]. Photo microscope prepared to get photos of the X100 and X200 objective lens (Nikkon).

The data collected in the form of the percentage of the power of expression analyzed use of the analysis $\mathrm{T}$ test (SPSS for a window 15). To know distinction the role of each interleukin incancer immunology.

\section{Result}

The expression of Il-2 and Il-10 (in percent) of the 17 samples of patients with cervical cancer. Five for IL-2 and IL-10 was in heavy category and 12sample for IL-2 and Il-10 was in moderate category (Table 1).

Another result of this experiment shows in Figure 1 and Figure 2. Results of immunohistochemical staining 
Table 1. The expression of Il-2 and Il-10 (in percent) of the 17 samples of patients with cervical cancer.

\begin{tabular}{ccccc}
\hline Cytokine Expression & \# Mild (5\% - 30\%) & \# Moderate $\mathbf{( 3 1 \% ~ - ~ 7 0 \% )}$ & \# Strong (71\% - 100\%) & Total \\
Il-2 & 5 & 12 & 0 & 17 \\
Il-10 & 5 & 12 & 0 & 17 \\
\hline
\end{tabular}
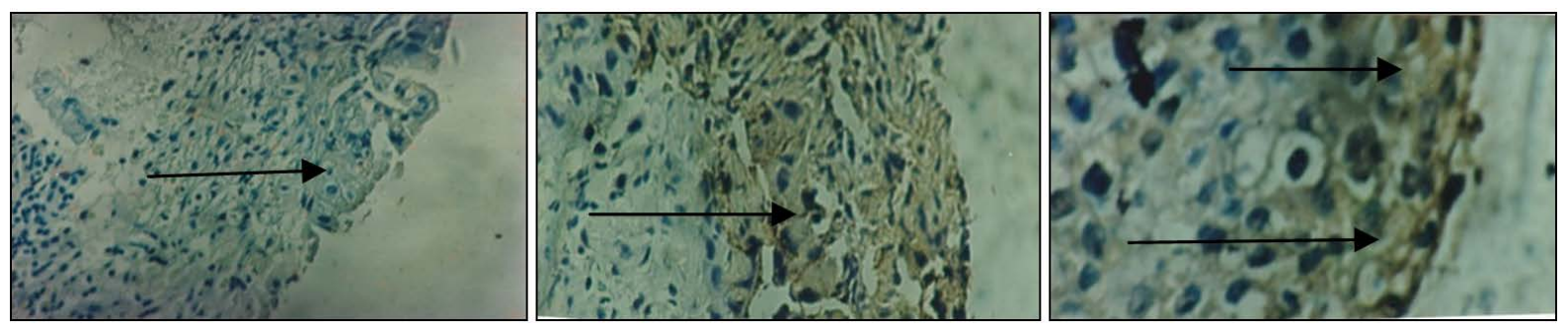

Figure 1. Results of immunohistochemical staining using monoclonal antibodies anti-IL-2. Brownish yellow color shows the expression of IL-2 in cervical cancer tissues (arrows). Visible expression categorized moderate (30\% - 70\%).
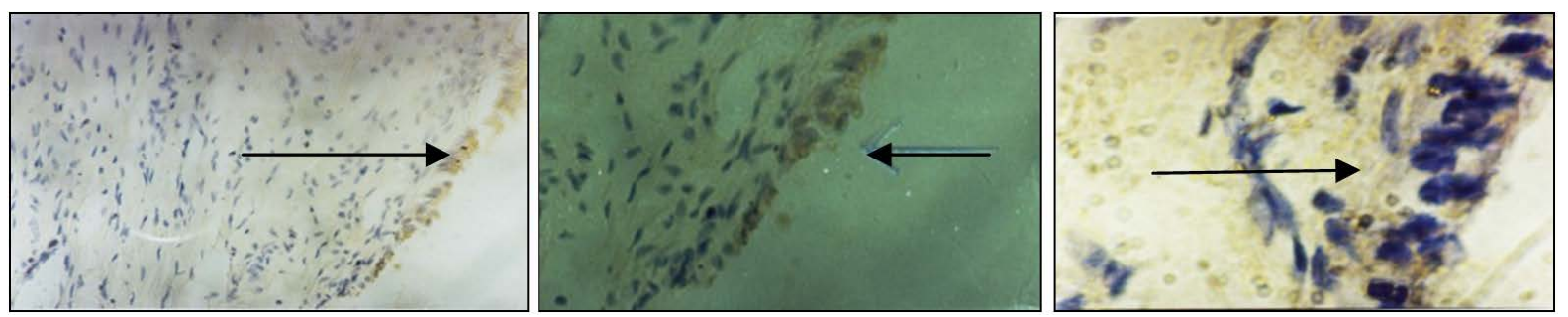

Figure 2. Results of immunohistochemical staining using monoclonal antibodies anti-IL-10. Brownish yellow color shows the expression of IL-10 in cervical cancer tissues (arrows). Visible expression categorized moderate (30\% - 70\%).

using monoclonal antibodies anti-IL-2. Brownish yellow color shows the expression of IL-2 in cervical cancer tissues (arrows). Visible expression categorized moderate (30\% - 70\%). Another results of immunohistochemical staining using monoclonal antibodies anti-IL-10. Brownish yellow color shows the expression of IL-10 in cervical cancer tissues (arrows). Visible expression categorized moderate (30\% - 70\%).

Comparison (Table 2) between IL-2 and IL-10 proteins produced by cervical cancer cells. In this studied the rate of expression of IL-10 was $45.3 \%$ (moderate) is more than the rate of expression of IL-2 $(35.9 \%=$ moderate).

From the analysis $t$ test he got the value of $p=0.153$ (Table 3), which means there's no a significant difference between an expression of IL2 with IL10 proteins. Which means acellular humoral immune response have the same parts on the occurrence of cervical cancer.

\section{Discussion}

Cytokines are regulators of host responses to infection, immune responses, inflammation, and trauma. Some cytokines act to make disease worse (proinflammatory), whereas others serve to reduce inflammation and promote healing (anti-inflammatory).Cytokines are nonstructural proteins with molecular weights ranging from 8 to 40,000 Da. For the most part, cytokines are primarily involved in host responses to disease or infection, and any involvement with homeostatic mechanisms [30]-[32]. Cytokines also known as a tool for communication between cells and do not have a specific target. Action of cytokines can paracrine or autocrine. Production and activity of cytokines will affect other cytokines, so it will form a complex cytokine system. In complex biological systems such as immunity, it would be necessary cytokines by cells to build optimal immunity ability [33]-[35].

Interleukin (IL)-2 play a role in immune tolerance. This idea is much different from the early paradigm in which IL-2 is central for protective immune responses. This change in thinking occurred when a T regulatory cell defect was shown to be responsible for the lethal autoimmunity associated with IL-2/IL-2R deficiency [36]. IL-2 was first known as T lymphocytes cell growth factor. This cytokine referenced from $\mathrm{T}$ lymphocyte cell 
Table 2. Comparison between the expression of IL-2 and IL-10 produced by cervical cancer cells.

\begin{tabular}{|c|c|c|}
\hline No. Sample & IL-2 (\%) & IL-10 (\%) \\
\hline 1 & 20 & 50 \\
\hline 2 & 40 & 60 \\
\hline 3 & 20 & 40 \\
\hline 4 & 50 & 30 \\
\hline 5 & 50 & 50 \\
\hline 6 & 40 & 40 \\
\hline 7 & 20 & 70 \\
\hline 8 & 50 & 30 \\
\hline 9 & 10 & 70 \\
\hline 10 & 40 & 50 \\
\hline 11 & 60 & 40 \\
\hline 12 & 40 & 50 \\
\hline 13 & 60 & 30 \\
\hline 14 & 40 & 60 \\
\hline 15 & 20 & 50 \\
\hline 16 & 10 & 30 \\
\hline 17 & 40 & 20 \\
\hline Mean & 35.9 & 45.3 \\
\hline
\end{tabular}

Table 3. Paired samples test between expression of IL2 and IL10.

\begin{tabular}{|c|c|c|c|c|c|c|c|c|c|}
\hline & & \multicolumn{5}{|c|}{ Paired Differences } & \multirow{3}{*}{$\mathrm{t}$} & \multirow{3}{*}{$\mathrm{df}$} & \multirow{3}{*}{$\begin{array}{c}\text { Sig. } \\
\text { (2-tailed) }\end{array}$} \\
\hline & & \multirow{2}{*}{ Mean } & \multirow{2}{*}{ Std. Deviation } & \multirow{2}{*}{ Std. Error } & \multicolumn{2}{|c|}{$\begin{array}{l}\text { 95\% Confidence Interval of the } \\
\text { Difference }\end{array}$} & & & \\
\hline & & & & & Lower & Upper & & & \\
\hline Pair & IL-2 - IL-10 & -9.41176 & 25.85309 & 6.27030 & -22.70420 & 3.88067 & -1.501 & 16 & 0.153 \\
\hline
\end{tabular}

growth factor, which is produced by T cells lymphocyte. IL-2 also works as a growth and differentiation factor for NK cells, some B lymphocytes and LAK cells [3]. In addition to IL-2 activates monocytes to produce cytokines, such as TNF alpha. Some tumor cells are very resistant to NK cells, but NK cells when incubated with IL-2 in vitro, the NK cells will turn into LAK cells are better able to destroy tumor cells. So that this cytokine is used for cancer immunotherapy [37].

Pleiotropic cytokine interleukin-10 (IL-10) has been implicated as an important regulator of the functions of lymphoid and myeloid cells. IL-10's ability to block activation of cytokine synthesis and several accessory cell functions of macrophage renders this cytokine a potent suppressor of the effector functions of macrophages, $\mathrm{T}$ cells, and NK cells. In addition, IL-10 likely contributes to regulating proliferation and differentiation of B cells, mast cells, and thymocytes [4] [38]. IL-10 is a cytokine that has a unique function, which can suppress the immune system and stimulate. IL-10 can suppress the production of IL-2, IL-3, TNF, GM-CSF and IFN-gamma and MHC II expression on macrophages. On the other hand IL-10 can stimulate B cell proliferation, antibody production, mastus-cell and thymosit growth [39] [41]. As cytokines produced by Th2 lymphocytes, IL-10 is thus suppressing Th1 activity will depress interferon gamma, IL-2, GM-CSF, and tumor necrosis factor alpha cytokine family. Reported that a lot of emphasis on the ability to suppress IL-10 gene expression and synthesis 
of cytokines proinflamatory. Recent research has suggested that the development of B lymphocytes and the production of immunoglobulin (Ig) is normal in IL-10-deficient mice. Concluded by him that IL-10 is a cytokine that is essential to compensate for the presence of proinflammatory cytokines [1] [42]. Here are IL-10 family of cytokines member consist IL-10, IL-19, IL-20, IL-22, IL-24, IL-26, and the more distantly related IL-28A, IL-28B, and IL-29. These cytokines elicit diverse host defense mechanisms from various infections, especially from epithelial cells. IL-10 family cytokines are essential for maintaining the homeostasis of tissue epithelial layers. Members of this family can promote innate immune responses from tissue epithelial to limit the damage caused by viral and bacterial infections. These cytokines can also facilitate the tissue-healing process in injuries caused by infection or inflammation. Finally, IL-10 itself can supresspro inflammatory responses and limit unnecessary tissue disruptions caused by inflammation [43].

The role of cytokine that is very large in terms of modulates immune systems. Therefore by knowing the expression of a cytokine we can determine immune system which most play a role.

\section{Conclusion}

It is indicated that the immune response plays a role in balance between cellular and humoral immunity.

\section{Acknowledgements}

We thank to Higher Education Competitive Research Project Ministry of Education and Culture Republic of Indonesia for Grand Featured Research Universities 2013, LPPT of Gajah Mada University and special thanks to acknowledge, Prof. Dr. Rafik Karsidi, MSc as a rector of Sebelas Maret University Surakarta Indonesia, Prof. Dr. Ir. Darsono, M. Si as a Chairman of the Institute for Research and Community Service, Prof. Dr. Zainal Arifin Adnan, SpPD-KR., FINASIM as a dean of Faculty of Medicine of Sebelas Maret University Surakarta Indonesia and special thanks to acknowledge Prof. Wihaskoro Sosroseno, DDS., Ph.D. for much inspirations to writethis article.

\section{References}

[1] Charles, A.D. and Lyle, L.M. (2000) Proinflammatory and Anti-Inflammatory Cytokines in Rheumatoid Arthritis. 2nd Edition, Amgen Inc., One Amgen Centre Drive, Thousand Oaks, 23-75.

[2] Bufler, P. (2011) Interleukin-37 as Fundamental Inhibitor of Innate Immunity. Arthritis Research \& Therapy, $13,2011$. http://dx.doi.org/10.1186/ar3419

[3] Malek, T.R. (2003) The Main Function of IL-2 Is to Promote the Development of T Regulatory Cells. Journal of Leukocyte Biology, 74, 961-965. http://dx.doi.org/10.1189/jlb.0603272

[4] Moore, K.W., O’Garra, A., de Waal Malefyt, R., Vieira, P. and Mosmann, T.R. (1993) Interleukin-10. The Annual Review of Immunology, 11, 165-190. http://dx.doi.org/10.1146/annurev.iy.11.040193.001121

[5] Adi, P. (2006) Cervical Cancer with Human Papilloma Virus and Epstein Barr Virus Positive. Journal of Carcinogenesis, 5, 2006. http://dx.doi.org/10.1186/1477-3163-5-13

[6] Chaturvedi, A.K. (2010) Beyond Cervical Cancer: Burden of Other HPV-Related Cancers among Men and Women. Journal of Adolescent Health, 46, 20-26. http://dx.doi.org/10.1016/j.jadohealth.2010.01.016

[7] Doll, R. and Peto, R. (1981) The Causes of Cancer: Quantitative Estimates of Avoidable Risks of Cancer in the United States Today. Journal of the National Cancer Institute, 66, 1191-1308.

[8] Kinzler, Kenneth, W. and Vogelstein, B. (2002) Introduction. The Genetic Basis of Human Cancer. 2nd Edition, McGraw-Hill, New York, Medical Publications Division.

[9] Khorasanizadeh, F., Hassanloo, J., Khaksar, N., Mohammad, T.S., Marzaban, M.H., Rasidi, B., Akbari, S.A., Zendehdel, K. (2013) Epidemiology of Cervical Cancer and Human Papilloma virus Infection among Iranian Women-Analyses of National Data and Systematic Review of the Literature. Gynecologic Oncology, 128, 277-281.

[10] Licciarone, J.C., Wilkins, J.R., Brownson, R.C. and Chang, J.C. (1989) Cigarette Smoking and Alcohol Consumption in the Aetiology of Uterine Cervical Cancer. International Journal of Epidemiology, 18, 533-537. http://dx.doi.org/10.1093/ije/18.3.533

[11] Elizabeth, A., Tara, N.R., Frannie, R.K., Chaterine, H. and Edward, S.P. (2009) Oral Cancer Knowledge, Attitude and Practices: A Survey of Dentist and Primary Care Physicians in Massachusetts. American Dental Association, 140, 461-467.

[12] Colin, R.Y. and Welsh, C.J. (2005) Stress Health and Disease. Cell Science. 
[13] Edgar, H.V., Maria, E.C. and Paola (2007) A Solar dan Fabian A Soto. Enhancement of Pavlovian Conditioned Immunosuppression in Rats. Acta Neurobiologiae Experimentalis, 67, 71-81.

[14] Prasanta, K.R. (1999) Stress Genes and Species Survival. Moleculer and Cellular Biochemistry. Springer Netherlands, 196, 117-123.

[15] Putra, S.T. (2005) Psikoneuroimunologi. Graha Masyarakat Ilmiah Kedokteran (GRAMIK) Fakultas Kedokteran UNAIR-RSU dr Sutomo. Surabaya.

[16] Elizabeth, C. (2007) Cell Stress Protein Linked to Breast Cancer.

[17] Colin, R. (2005) Young dan C. Jane Welsh. Stress Health and Disease. Cell Science.

[18] Alberto, J.L. and Macario, M.D. (2005) dan Everly Conway de Macario. Sick Chaperones, Cellular Stress, and Disease. NEJM, 353, 1489-1501. http://dx.doi.org/10.1056/NEJMra050111

[19] Sunitha, C. and Gabriel, R. (2004) Oral Cancer at a Glance. The Internet Journal of Dental Science, 1, 2004.

[20] Mehrotra Ravi dan Yadav, S. (2006) Oral Squamous Cell Carcinoma: Etiology, Pathogenesis and Prognostic Value of Genomic Alterations. Indian Journal of Cancer, 43, 60-66. http://dx.doi.org/10.4103/0019-509X.25886

[21] Coussens, L.M. and Werb, Z. (2002) Inflammation and Cancer. Nature, 420, 860-867.

[22] Keibel, A., Singh, V. and Sharma, M.C. (2009) Inflammation, Microenvironment, and the Immune System in Cancer Progression. Current Pharmaceutical Design, 15, 1949-1955. http://dx.doi.org/10.2174/138161209788453167

[23] Weber, D., Wheat, J.M. and Curri, G.M. (2010) Inflammation and Cancer: Tumor Initiation, Progression and Metastasis, and Chinese Botanical Medicines. Journal of Chinese Integrative Medicine, 8, 1006-1013. http://dx.doi.org/10.3736/jcim20101101

[24] Hoyer, K.K., Doom, H., Barron, L. and Abbas, A.K. (2008) Interleukin-2 in the Development and Control of Inflammatory Disease. Immunological Reviews, 226, 19-28. http://dx.doi.org/10.1111/j.1600-065X.2008.00697.x

[25] Botti, C., Seregni, E., Ferrari, L., Martinetti, A. and Bombardieri, E. (1998) Immunosuppressive Factors: Role in Cancer Development and Progression. International Journal of Biological Markers, 13, 51-69.

[26] Beckebaum, S., Zhang, X., Chen, X., Yu, Z., Frilling, A., Dworacki, G., Grosse-Wilde, H., Broelsch, C.E., Gerken, G. and Cicinnati, V.R. (2004) Increased Levels of Interleukin-10 in Serum from Patients with Hepatocellular Carcinoma Correlate with Profound Numerical Deficiencies and Immature Phenotype of Circulating Dendritic Cell Subsets. Clinical Cancer Research, 10, 7260-7269. http://dx.doi.org/10.1158/1078-0432.CCR-04-0872

[27] Kim, R., Emi, M., Tanabe, K. and Arihiro, K. (2006) Tumor-Driven Evolution of Immunosuppressive Networks during Malignant Progression. Cancer Research, 66, 5527-5536. http://dx.doi.org/10.1158/0008-5472.CAN-05-4128

[28] IHC \& ISH Advanced Staining (2013) Tutorial. An Animated Guide to Immunohistochemistry. http://www.LeicaBiosystem.com

[29] Kim, S.H., Shin, Y.K., Lee, K.M., Lee, J.S., Yun, J.H. and Lee, S.M. (2003) An Improved Protocol of Biotinylated Tyramine-Based Immunohistochemistry Minimizing Nonspecific Background Staining. Journal of Histochemistry \& Cytochemistry, 51, 129-132. http://dx.doi.org/10.1177/002215540305100116

[30] Dinarello, C.A. (2000) Proinflammatory Cytokines. Chest, 118, 503-508. http://dx.doi.org/10.1378/chest.118.2.503

[31] Elenkov, I.J., Lezzoni, D.G., Daly, A., Harris, A.G. and Chrouros, G.P. (2005) Cytokine Dysregulation, Inflammation and Well-Being. Neuroimmunomodulation, 12, 255-269. http://dx.doi.org/10.1159/000087104

[32] Bamias, G., Corridoni, D., Pizarro, T.T. and Cominelli, F. (2012) New Insights into the Dichotomous Role of Innate Cytokines in Gut Homeostasis and Inflammation. Cytokine, 59, 451-459. http://dx.doi.org/10.1016/j.cyto.2012.06.014

[33] Trinchieri, G., Kubin, M., Bellone, G. and Cassatella, M.A. (1993) Cytokine Cross-Talk between Phagocytic Cells and Lymphocytes: Relevance for Differentiation/Activation of Phagocytic Cells and Regulation of Adaptive Immunity. Journal of Cellular Biochemistry, 53, 301-308. http://dx.doi.org/10.1002/jcb.240530406

[34] Shen-Orr, S.S., Goldberger, O., Garten, Y., Rosenberg-Hasson, Y., Lovelace, P.A., Hirschberg, D.L., Altman, R.B., Davis, M.M. and Butte, A.J. (2009) Towards a Cytokine-Cell Interaction Knowledgebase of the Adaptive Immune System. Pacific Symposium on Biocomputing, 2009, 439-450.

[35] Benedict, K.F. and Lauffenburger, D.A. (2013) Insights into Proteomic Immune Cell Signaling and Communication via Data-Driven Modeling. Current Topics in Microbiology and Immunology, 363, 201-233. http://dx.doi.org/10.1007/82_2012_249

[36] Malek, T.R. (2008) The Biology of Interleukin-2. Annual Review of Immunology, 26, 453-479. http://dx.doi.org/10.1146/annurev.immunol.26.021607.090357

[37] Kimura, H. and Yamaguchi, Y. (1989) Adoptive Immunotherapy with LAK Cell and IL-2 against Primary Lung Cancer. Nihon Rinsho Geka Gakkai Zasshi, 90, 1459-1462.

[38] Wolk, K., Kunz, S., Asadullah, K. and Sabat, R. (2002) Cutting Edge: Immune Cells as Sources and Targets of the 
IL-10 Family Members? Journal of Immunology, 168, 5397-5402.

[39] Itoh, K. and Hirohata, S. (1995) The Role of IL-10 in Human B Cell Activation, Proliferation, and Differentiation. Journal of Immunology, 154, 4341-4350.

[40] Sabat, R., Grutz, G., Warszawska, K., Kirsch, S., Witte, E., Wolk, K. and Geginat, J. (2010) Biology of Interleukin-10. Cytokine \& Growth Factor Reviews, 21, 331-344. http://dx.doi.org/10.1016/j.cytogfr.2010.09.002

[41] Bouaziz, J.D., Calbo, S., Maho-Vaillant, M., Saussine, A., Bagot, M., Bensussan, A. and Musette, P. (2010) IL-10 Produced by Activated Human B Cells Regulates CD4 ${ }^{+}$T-cell Activation in vitro. European Journal of Immunology, 40, 2686-2691. http://dx.doi.org/10.1002/eji.201040673

[42] Lalani, I., Bhol, K. and Ahmed, A.R. (1997) Interleukin-10: Biology, Role in Inflammation and Autoimmunity. Annals of Allergy, Asthma \& Immunology, 79, 469-484. http://dx.doi.org/10.1016/S1081-1206(10)63052-9

[43] Ouyang, W., Rutz, S., Crellin, N.K., Valdez, P.A. and Hymowitz, S.G. (2011) Regulation and Functions of the IL-10 Family of Cytokines in Inflammation and Disease. Annual Review of Immunology, 29, 71-109. http://dx.doi.org/10.1146/annurev-immunol-031210-101312 